\title{
Effect of Propionic Acid on Fatty Acid Oxidation and Ureagenesis
}

\author{
ALLEN M. GLASGOW ${ }^{(23)}$ AND H. PETER CHASE \\ University of Colorado Medical Center, B. F. Stolinsky Laboratories, Denver, Colorado, USA
}

\begin{abstract}
Extract
Propionic acid significantly inhibited ${ }^{14} \mathrm{CO}_{2}$ production from $\left[1-{ }^{14} \mathrm{C}\right]$ palmitate at a concentration of $10 \mu \mathrm{M}$ in control fibroblasts and $100 \mu \mathrm{M}$ in methylmalonic fibroblasts. This inhibition was similar to that produced by 4-pentenoic acid. Methylmalonic acid also inhibited ${ }^{14} \mathrm{CO}_{2}$ production from $\left[1-{ }^{14} \mathrm{C}\right]$ palmitate, but only at a concentration of $1 \mathrm{mM}$ in control cells and $5 \mathrm{mM}$ in methylmalonic cells.

Propionic acid $(5 \mathrm{mM})$ also inhibited ureagenesis in rat liver slices when ammonia was the substrate but not with aspartate and citrulline as substrates. Propionic acid had no direct effect on either carbamyl phosphate synthetase or ornithine transcarbamylase.

These findings may explain the fatty degeneration of the liver and the hyperammonemia in propionic and methylmalonic acidemia.

\section{Speculation}

It has been shown that 4-pentenoic acid will produce many of the features of Reye's syndrome in rats. The fact that propionic acid inhibits some of the same reactions as 4 -pentenoic acid raises the possibility that other short chain fatty acids less unusual than 4-pentenoic acid could produce the features of Reye's syndrome.
\end{abstract}

Propionic and methylmalonic acidemias are rare inborn errors of metabolism. These disorders have some of the same features, such as hyperammonemia (15) and fatty degeneration of the liver $(8,11,12)$, as those of Reye's syndrome. Massive accumulation of a specific short chain is one obvious difference. It has been speculated that short chain fatty acids may be an endogenous toxin in Reye's syndrome $(10,16,18)$.

4-Pentenoic acid will produce hyperammonemia, hypogiycemia, and fatty degeneration of the liver in rats and has been proposed as a possible model for Reye's syndrome (4). We reasoned that perhaps the mechanism of hyperammonemia and fatty degeneration of the liver in propionic acidemia and methylmalonic acidemia was similar to the mechanism in 4-pentenoic acid-treated rats.

4-Pentenoic acid is known to inhibit the oxidation of fatty acids and it is thought that this accounts for some of the other features of its toxicity such as the hypoglycemia (15). 4-Pentenoic acid also inhibits ureagenesis, probably at either the step of carbamyl phosphate synthetase or mitochondrial ornithine uptake (5). Results of the present study show that propionic acid also inhibits fatty acid oxidation and ureagenesis, which may explain the fatty degeneration of the liver and the hyperammonemia often associated with propionic acidemia.

\section{METHODS}

\section{FATTY ACID OXIDATION}

Fibroblasts from a skin biopsy of a patient with $\mathrm{B}_{12}$-unresponsive methylmalonic acidemia and a control patient were stored in liquid nitrogen until used. The cells, grown to confluence in Eagle's essential medium with $15 \%$ fetal calf serum, were washed with phosphate-buffered saline, harvested with a brief treatment with trypsin-EDTA, washed twice with phosphate-buffered saline, and then suspended in phosphate-buffered saline (145 $\mathrm{mM} \mathrm{Na}, 4.15$ $\left.\mathrm{mM} \mathrm{K}, 140 \mathrm{~m} \mathrm{M} \mathrm{Cl}, 9.36 \mathrm{mM} \mathrm{PO}_{4}, \mathrm{pH} 7.4\right)$. In most cases the cells were incubated in $3 \mathrm{ml}$ phosphate-buffered saline containing 0.5 $\mu \mathrm{Ci}\left[1-{ }^{14} \mathrm{C}\right]$ palmitate (19), final concentration approximately $3 \mu \mathrm{M}$ added in $10 \mu \mathrm{l}$ hexane. Increasing the amount of hexane to $100 \mu \mathrm{l}$ did not impair palmitate oxidation. In two experiments (Fig. 3) the fibroblasts were incubated in $3 \mathrm{ml}$ calcium-free Krebs-Ringer phosphate buffer (2) containing $5 \mathrm{~g} / 100 \mathrm{ml}$ essentially fatty acid free bovine serum albumin (20), $1 \mathrm{mM}$ palmitate, and the same amount of $\left[1-{ }^{14} \mathrm{C}\right]$ palmitate as above. Other compounds were added as indicated in the tables and figures. Fibroblasts were always added last. All incubations were for $1 \mathrm{hr}$ at $37^{\circ}$ under $100 \%$ $\mathrm{O}_{2}$ shaken at $120 \mathrm{cpm}$ in a Dubnoff metabolic bath. Flasks were 50 $\mathrm{ml}$ with a side arm for a scintillation vial that contained a strip of filter paper $(2.5$ by $5 \mathrm{~cm})$ saturated with $0.1 \mathrm{ml} \mathrm{I} \mathrm{M} \mathrm{hyamine}$ hydroxide in methanol (21). Since hyamine inhibited the oxidation of palmitate, the main compartment and the scintillation vial were separated by a piece of aluminum foil during the incubation. The reaction was stopped by the injection of $0.5 \mathrm{ml} 10 \mathrm{M} \mathrm{H}_{2} \mathrm{SO}_{4}$ and the foil was widely ruptured with a long curved needle; $\mathrm{CO}_{2}$ was completely collected during a further 30 -min incubation. The scintillation vial was then removed and $10 \mathrm{ml}$ scintillation fluid added. After sitting overnight at $4^{\circ}$ the samples were counted in a scintillation counter (22). Counting efficiency was consistently between $77 \%$ and $80 \%$ as determined using a ${ }^{137} \mathrm{Cs}$ external standard. Since all comparisons made are between fibroblasts from the same suspension and incubated at the same time, results were standardized by dividing the counts for individual flasks by the mean number of counts in the control flasks and multiplying by 100.

Protein was determined by the method of Lowry (9) with bovine serum albumin as standard.

\section{UREAGENESIS}

The method for the determination of urea production in liver slices is reported in detail elsewhere (5). Briefly, rat liver slices were incubated for $2 \mathrm{hr}$ in $\mathrm{K}$ rebs-Ringer phosphate buffer containing the additions indicated in Table 3 . A neutralized perchloric extract of the tissue plus medium was passed through a column $(0.5$ by $5 \mathrm{~cm}$ ) of anion exchange resin to remove ammonia and urea was determined by hydrolysis with urease followed by the measurement of the liberated ammonia with phenol-hypochlorite. Baseline urea was measured in a similar fashion allowing the calculation of net production or urea per g wet weight for a 2 -hr incubation.

Carbamyl phosphate synthetase and ornithine transcarbamylase were assayed as previously described (5).

\section{RESULTS}

\section{FATTY ACID OXIDATION}

Propionic acid significantly inhibited palmitate oxidation at a concentration of $0.01 \mathrm{mM}$ and above in "control" fibroblasts and 
Table 1. Effect of Propionic, 4-pentenoic, methylmalonic, and butyric acid on ${ }^{14} \mathrm{CO}_{2}$ production from $\left[1-{ }^{14} \mathrm{C}\right]$ palmitate in control fibroblasts $^{1}$

\begin{tabular}{|c|c|c|c|c|c|c|}
\hline \multirow[b]{2}{*}{ Inhibitor } & \multicolumn{6}{|c|}{${ }^{14} \mathrm{CO}_{2}$ production (mean $\pm 1 \mathrm{SD}$ ) for various conc. of inhibitor } \\
\hline & $0 \mathrm{mM}$ & $0.001 \mathrm{mM}$ & $0.01 \mathrm{mM}$ & $0.1 \mathrm{mM}$ & $1 \mathrm{mM}$ & $5 \mathrm{mM}$ \\
\hline Propionic acid & $100 \pm 3.0$ & $91.3 \pm 8.4$ & $\begin{array}{c}88.2 \pm 4.0 \\
p<0.001\end{array}$ & $\begin{array}{c}76.3 \pm 3.1 \\
p<0.001\end{array}$ & $\begin{array}{c}50.4 \pm 6.0 \\
p<0.001\end{array}$ & $\begin{array}{l}52.4 \pm 3.3 \\
p<0.001\end{array}$ \\
\hline 4-Pentenoic acid & $100 \pm 15.3$ & $99.0 \pm 14.0$ & $98.2 \pm 11.2$ & $\begin{array}{c}65.4 \pm 6.5 \\
p<0.01\end{array}$ & $\begin{array}{c}62.9 \pm 3.9 \\
p<0.001\end{array}$ & $\begin{array}{l}70.1 \pm 9.7 \\
p<0.01\end{array}$ \\
\hline Methylmalonic acid & $100 \pm 12.5$ & $96.7 \pm 9.6$ & $90.0 \pm 16.2$ & $89.1 \pm 10.6$ & $\begin{array}{c}83.0 \pm 7.6 \\
p<0.05\end{array}$ & $\begin{array}{l}81.1 \pm 5.9 \\
p<0.02\end{array}$ \\
\hline Butyric acid & $100 \pm 7.8$ & & & $\begin{array}{c}87.5 \pm 8.5 \\
p<0.05\end{array}$ & $\begin{array}{c}85.6 \pm 12.0 \\
p<0.05\end{array}$ & $\begin{array}{l}84.3 \pm 8.1 \\
p<0.02\end{array}$ \\
\hline
\end{tabular}

${ }^{1}$ Results are expressed as a percentage of the mean ${ }^{14} \mathrm{CO}_{2}$ production in flasks with no addition. Results are the mean $\pm 1 \mathrm{SD}$ of five samples. The Student $t$-test was used to compare results with various concentrations of inhibitor with results with no addition. If $p>0.05$ no $p$ value is given. The mean oxidation of palmitate in flasks with no addition (assuming no dilution by endogenous substrate) was 168,208 , and $19610^{-12} \mathrm{~mol} / \mathrm{mg}$ protein/hr in the propionic 4-pentenoic and methylmalonic acid experiments, respectively. Protein was not determined in the butyric acid experiment.

Table 2. Effect of propionic, 4-pentenoic, and methylmalonic acid on ${ }^{14} \mathrm{CO}_{2}$ production from $\left[1-{ }^{14} \mathrm{C}\right]$ palmitate in methylmalonic fibroblasts ${ }^{1}$

${ }^{14} \mathrm{CO}_{2}$ production (mean $\pm \mathrm{SD}$ ) for various conc. of inhibitor, \%

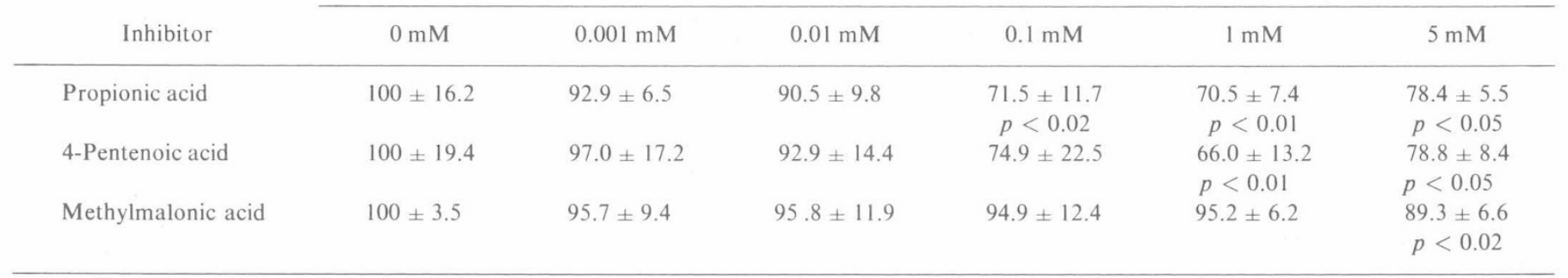

${ }^{1}$ Results are expressed as a percentage of the mean ${ }^{14} \mathrm{CO}_{2}$ production in flasks with no addition. Results are the mean \pm 1 SD of five samples. The Student $t$-test was used to compare results with various concentrations of inhibitor with results with no addition. If $p>0.05$ no $p$ value is given. The mean oxidation of palmitate in flasks with no addition (assuming no dilution by endogenous substrate) was 196, 193, and $22510^{-12} \mathrm{~mol} / \mathrm{mg}$ protein/hr in the propionic, 4-pentenoic, and methylmalonic acid experiments, respectively.

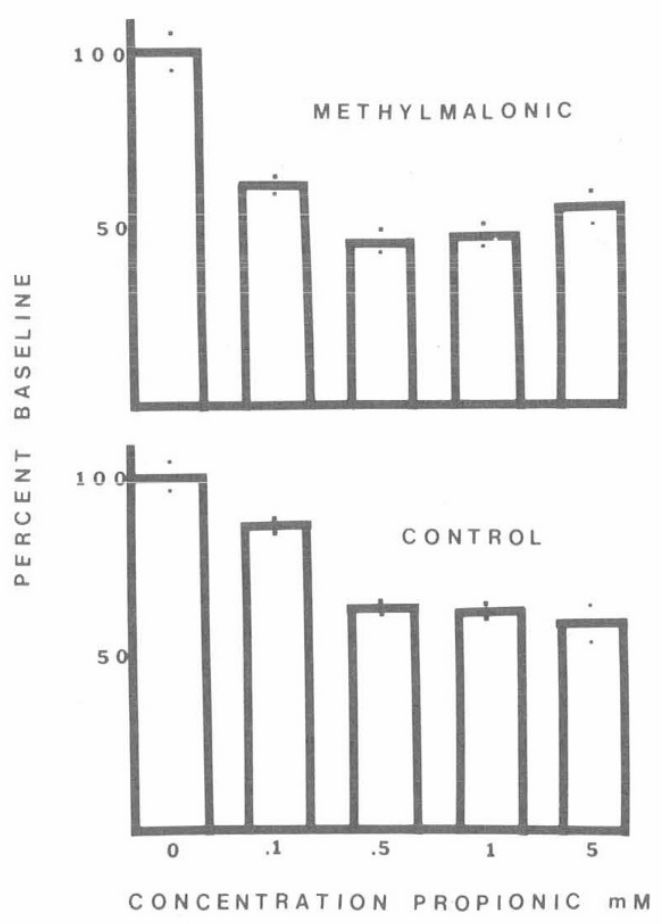

Fig. 1. Effect of propionic acid on ${ }^{14} \mathrm{CO}_{2}$ production from $\left[1-{ }^{14} \mathrm{C}\right]$ palmitate in the presence of $1 \mathrm{mM}$ palmitate and $5 \mathrm{~g} / 100 \mathrm{ml}$ bovine serum albumin in methylmalonic and control cells. Each bar represents the mean of two samples. at a concentration of $0.1 \mathrm{mM}$ and above in methylmalonic fibroblasts (Tables 1 and 2). This inhibition is very similar both in the concentration required and in the extent of inhibition to that produced by 4 -pentenoic acid in the same system (Tables 1 and 2). Methylmalonic acid was significantly inhibitory only at a concentration of $1 \mathrm{mM}$ in control cells and $5 \mathrm{mM}$ in methylmalonic cells (Tables 1 and 2). Butyric acid, the only other short chain fatty acid tested, inhibited ${ }^{14} \mathrm{CO}_{2}$ production at the lowest concentration tested $(0.1 \mathrm{mM}$ in "control" cells (Table 1$))$.

Propionic acid also inhibited palmitate oxidation when palmitate was present in a $1 \mathrm{mM}$ concentration (Fig. 1).

\section{UREAGENESIS}

Propionic acid in a concentration of $5 \mathrm{mM}$ significantly $(P<$ 0.02 ) inhibited ureagenesis in rat liver slices with ammonia as substrate (Table 3 ). Propionic acid did not significantly inhibit urea production with aspartate and citrulline as substrates (Table $3)$. The extent of the inhibition with ammonia as substrate was about the same when ornithine was also present (Table 3). Propionic acid did not directly inhibit either carbamyl phosphate synthetase or ornithine transcarbamylase (Table 4).

\section{DISCUSSION}

Patients with propionic acidemia may have plasma concentrations of propionic acid as high as $5.4 \mathrm{mM}$ (8). Patients with methylmalonic acidemia may have plasma concentrations of methylmalonic acid of $3 \mathrm{mM}$ and may also have elevated propionic acid levels $(1,11)$. Thus, the concentrations of short chain fatty acids used in this study are within the range that might be expected in patients with these disorders. 
PROPIONIC ACID: FATTY ACID OXIDATION AND UREAGENESIS

Table 3. Effect of propionic acid on ureagenesis in rat liver slices ${ }^{1}$

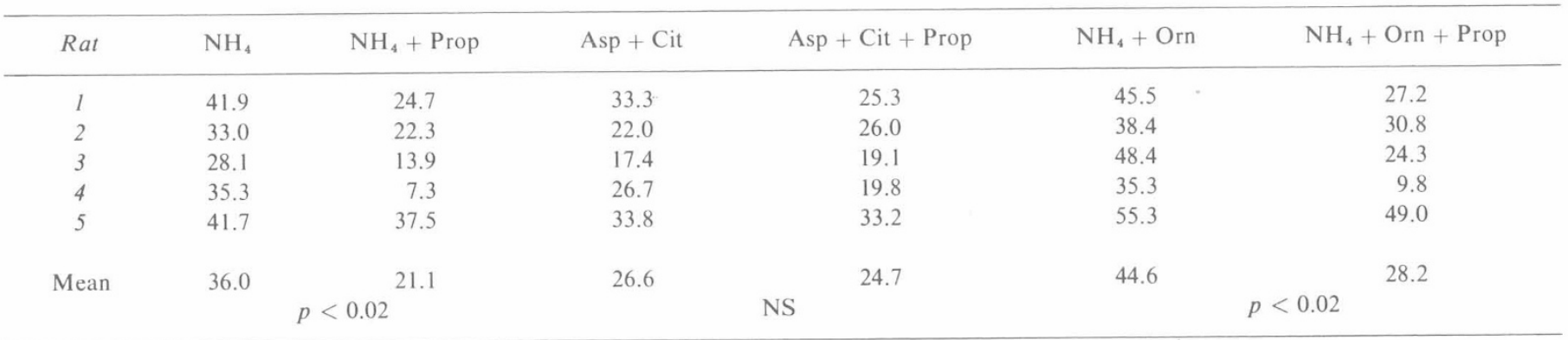

${ }^{1}$ Results are in micromoles of urea produced per g wet weight per $2 \mathrm{hr}$. $\mathrm{NH}_{4}$, aspartate (Asp), and citrulline (Cit) were added in a final concentration of $10 \mathrm{mM}$, ornithine (Orn) $2 \mathrm{mM}$, propionic acid (Prop), $5 \mathrm{mM}$.

Table 4. Effect of propionic acid on carbamyl phosphate synthetase and ornithine transcarbamylase ${ }^{1}$

\begin{tabular}{lcc}
\hline \multicolumn{1}{c}{ Enzyme } & $\begin{array}{c}\text { No propionic } \\
\text { acid, } \\
\mu \mathrm{M} / \mathrm{g} \text { wet wt } / \mathrm{hr}\end{array}$ & $\begin{array}{c}5 \mathrm{mM} \text { propionic } \\
\text { acid, } \\
\mu \mathrm{M} / \mathrm{g} \text { wet wt } / \mathrm{hr}\end{array}$ \\
\hline Carbamyl $\mathrm{PO}_{4}$ synthetase & $561 ; 560$ & $581 ; 555$ \\
Ornithine transcarbamylase & 13,$900 ; 12,300$ & 14,$300 ; 13,300$ \\
\hline
\end{tabular}

${ }^{1}$ Enzyme activity was determined in duplicate using liver from one rat.

Elevated propionic acid concentrations have also been observed in Reye's syndrome (up to $0.24 \mathrm{mM}$ (17)). Thus, patients with this disorder have levels of propionic acid equivalent to those found to inhibit fatty acid oxidation in fibroblasts, but lower than the concentration found to consistently inhibit ureagenesis.

These studies were done with fibroblasts since neither propionic nor methylmalonic acid can be metabolized via the major pathway by fibroblasts from the patient with methylmalonic acidemia. Thus, the inhibition of fatty acid oxidation observed with these compounds in these cells is not because they serve as an alternate source of energy. This is not the case with butyric acid which may have reduced palmitate oxidation by serving as an alternate fuel. On the other hand, the control cells can oxidize propionic and methylmalonic acid. Thus, the inhibition observed with these cells may be simple substrate competition. This makes difficult any comparison of the inhibition in control and methylmalonic fibroblasts.

The mechanism of the inhibition of nalmitate oxidation in these experiments is unknown. The inhibi could be anywhere from the uptake of palmitate to the final oy ition of acetyl-CoA in the citric acid cycle. Two possibilities are a olock caused either by $(l)$ depletion of free CoA or carnitine or both, or (2) a direct effect of the acyl-CoA on an enzyme or transport process.

Examples of the inhibition of fatty acid oxidation by both mechanisms are known. Pentanoic and cyclopropane carboxylic acids, which inhibit palmitate oxidation in rat liver mitochondria to about the same extent and at the same inhibitor concentration as observed with propionic and 4-pentenoic acids in this study, probably inhibit fatty acid oxidation by depleting free $\mathrm{CoA}$ and perhaps carnitine $(3,7,13,14)$.

The inhibition of fatty acid oxidation by 4-pentenoic acid in rat liver mitochondria is probably by the second mechanism, the direct inhibition of an enzyme by a CoA derivative. Although 4-pentenoic acid also depletes $\mathrm{CoA}$ it is a more potent inhibitor of fatty acid oxidation than pentanoic and cyclopropane carboxylic acids which deplete $\mathrm{COA}$ to a similar extent $(7,14)$. A metabolite of 4-pentenoic acid, 2,4-pentdienoyl-CoA, is a potent inhibitor of pig heart acetoacetyl-CoA thiolase, an enzyme of fatty acid oxidation (6).

The present experiments do not allow distinction between these and other possible mechanisms as the cause of the inhibition of fatty acid oxidation by propionic acid in fibroblasts. Since depletion of $\mathrm{CoA}$ (and carnitine) seems to occur with a number of nonmetabolizable or slowly metabolizable short chain fatty aicds, we believe this is the most likely mechanism for propionic acid. If so, then the oxidation of propionyl-CoA in control fibroblasts must be slow enough to allow its accumulation or, alternately, the inhibition in control fibroblasts may be simple substrate competition. The fact that 4-pentenoic acid is not a more potent inhibitor of fatty acid oxidation suggests that the inhibition of acetoacetyl-CoA thiolase by 2,4-pentdienoyl-CoA may not be important in this species in this tissue.

If propionic acid inhibits fatty acid oxidation in the liver and if propionic acid inhibits fatty acid oxidation more than it inhibits esterification, this could account for the fatty degeneration of the liver in propionic acidemia.

Propionic acid also inhibited ureagenesis from ammonia in rat liver slices. The lack of inhibition of ureagenesis by propionic acid with aspartate and citrulline as substrates suggests that the block is either at the carbamyl phosphate synthetase or the ornithine transcarbamylase steps. Patients with argininosuccinate synthetase, argininosuccinase, or argininase deficiencies have elevated plasma citrulline, argininosuccinate and arginine, respectively (16). The fact that these compounds do not accumulate in propionic acidemia (8) indicates that the block in the urea cycle in patients with this disorder probably precedes these steps. The inhibition of ureagenesis caused by propionic acid was about the same when ornithine was added and there was no direct effect of propionic acid on either carbamyl phosphate synthetase or ornithine transcarbamylase, suggesting the block is not due to depletion of ornithine or a direct enzyme inhibition by propionic acid. A number of possible sites for the block include: $(1)$ a direct enzyme inhibition by a metabolite of propionic acid such as propionyl-CoA (2) inhibition of the transport of citrulline or ornithine across the mitochrondrial membrane or (3) depletion of a substrate for the carbamyl phosphate synthetase step. In any case, the inhibition or ureagenesis by propionic acid may explain the hyperammonemia observed in propionic acidemia.

\section{SUMMARY}

Propionic acid inhibits ${ }^{14} \mathrm{CO}_{2}$ production from palmitate in both control and methylmalonic fibroblasts. This inhibition was similar to that produced by 4-pentenoic acid. Propionic acid also inhibited ureagenesis in rat liver slices. These findings may explain the fatty degeneration of the liver and hyperammonemia in propionic and methylmalonic acidemia.

\section{REFERENCES AND NOTES}

1. Ando, T., Rasmussen, K., Nyhan, W. I., Donnell, G. N., and Barnes, N. D. Propionic acidemia in patients with ketotic hyperglycinemia. J. Pediat., 78. $827(1971)$.

2. Cohen, P. P.: In: p. 149 Manometric Techniques, W. W. Umbriet, R. H. Burris, and J. F. Stauffer: (Burgis Publishing Company, Minneapolis, 1957).

3. Duncombe, W. G., and Rising, T. J.: Studies on the hypoglycaemic compound cyclopropanecarboxylic acid. Biochem. Pharmacol., 21: 1075 (1972).

4. Glasgow, A. M., and Chase, H. P.: Production of the features of Reye's syndrome in rats with 4-pentenoic acid. Pediat. Res., 9: 133 (1973). 
5. Glasgow, A. M., and Chase, H. P.: Effect of pent-4-enoic, propionic and other short chain fatty acids on citrulline synthesis in rat liver mitochondria. Biochem. J. (in press.)

6. Holland, P. C., Senior, A. E., and Sherratt, H. S.A.: Biochemical effects of the hypoglycaemic compound pent-4-enoic acid and related nonhypoglycaemic fatty acids. Biochem. J., 136: 173 (1973).

7. Holland, P. C., and Sherratt, H. S. A.: Biochemical effects of the hypoglycaemic compound pent-4-enoic acid and related nonhypoglycaemic fatty acids. Biochem. J., 136: 157 (1973).

8. Hommes, F. A., Kuipers, J. R. G., Elema, J. D., Jansen, J. F., and Jonxis, J. H. P.: Propionic acidemia a new inborn error of metabolism. Pediat. Res., 2: $519(1968)$.

9. Lowry, O. H., Rosebrough, N. J., Farr, A. L., and Randall, R. J.: Protein measurements with the Folin phenol reagent. J. Biol. Chem., 193: 265 (1951).

10. Mamunes, P., Devries, G. H., Miller, C. D., and David, R. B.: Fatty acids in Reye's syndrome. Pediat. Res., 8: 436 (1974).

11. Morrow, G., Barness, L. A., Auerback, V. H., DiGeorge, A. M. Ando, T., and Nyhan, W. L.: Observations on the coexistence of methylmalonic acidemia and glycinemia. J. Pediat., 74: 680 (1969).

12. Oberholzer, V. G., Levin, B., Burgess, E. A., and Young, W. F.: Methylmalonic aciduria an inborn error of metabolism leading to chronic metabolic acidosis. Arch. Dis. Childhood, 42: 492 (1967).

13. Senior, A. E., and Sherratt, H. S. A.: Biochemical effects of the hypoglycaemic compound pent-4-enoic acid and related nonhypoglycaemic fatty acids. Bio- chem. J., 110: 499 (1968)

14. Senior, A. E., Robson, B., and Sherratt, H. S. A.: Biochemical effects of the hypoglycaemic compound pent-4-enoic acid and related nonhypoglycaemic fatty acids. Biochem. J., 110: 511 (1968).

15. Sherratt, H. S. A.: Hypoglycin and related hypoglycaemic compounds. Brit. Med. Bull., 25: 250 (1969).

16. Shib, V E and Efron, M L. Urea cycle disorders. In: J. B Stanbury, J. B. Wyngaarden, and D. S. Fredrickson: The Metabolic Basis of Inherited Disease, Ed. 3, pp. 370-392 (McGraw-Hill Book Co., New York, 1972).

17. Sinatra, F., Yoshida, T., Applebaum, M., Mason, W., Hoogenraad, N. H., and Sunshine, P.: Abnormalities of carbamyl phosphate synthetase and ornithine transcarbamylase in liver of patients with Reye's syndrome. Pediat. Res., 9: 829 (1975).

18. Trauner, D. A., Hyhan, W L., and Sweetman, L. Short chain organic acidemia and Reye's syndrome. Neurology, 25: 296 (1975).

19. New England Nuclear, Boston, Mass

20. Sigma, St. Louis, Mo.

21. Amersham Searle, Arlington Heights, III.

22. Liquimat Picker Nuclear, White Plains, N. Y

23. Requests for reprints should be addressed to: A. M. Glasgow, M.D., Children's Hospital National Medical Center, 2125 13th St., Washington, D. C. 20009 (USA).

24. Accepted for publication February 17, 1976
Familial hyperlysinemia lysine

fibroblasts

genetic disease

liver lysine-ketoglutarate reductase saccharopine dehydrogenase saccharopine oxidoreductase

\title{
Multiple Enzyme Defects in Familial Hyperlysinemia
}

\author{
J. DANCIS, ${ }^{(30)}$ J. HUTZLER, N. C. WOODY, AND R. P. COX \\ Department of Pediatrics and Department of Medicine, New York University School of Medicine, New York, New York; and \\ Department of Pediatrics, Tulane University School of Medicine, New Orleans, Louisiana, USA
}

\section{Extract}

Lysine-ketoglutarate reductase (EC. 1.5.1.8) deficiency in skin fibroblasts has been previously reported in patients with familial hyperlysinemia, providing an adequate explanation for the biochemical derangements noted clinically. In the present study, analysis of liver obtained at autopsy from a patient with familial hyperlysinemia confirmed the lysine-ketoglutarate reductase deficiency but, unexpectedly, also revealed an absence of saccharopine dehydrogenase (EC. 1.5.1.9) and saccharopine oxidoreductase activity. Skin fibroblasts from two siblings with the disease and a third patient from an unrelated family were also deficient in all three enzymes (lysine-ketoglutarate reductase, average 9\%; saccharopine dehydrogenase, average $4 \%$; saccharopine oxidoreductase, $<10 \%$ of normal). The possibility that saccharopine dehydrogenase is a substrate-inducible enzyme was investigated by maintaining normal skin fibroblasts in a medium with minimal lysine concentration, and exposing hyperlysinemic fibroblasts to elevated saccharopine concentrations. There was no significant modification in saccharopine dehydrogenase activity.

\section{Speculation}

Multiple enzyme defects have now been recognized in three genetic diseases, maple syrup urine disease, orotic aciduria, and hyperlysinemia, presumably arising from single mutations. It is not unlikely that additional examples will emerge as investigators increase their efforts in this direction. The simultaneous loss of enzymes may provide insights into mechanisms of control and/or the evolutionary development of enzymes.

Familial diseases with a Mendelian pattern of inheritance are generally attributed to mutation of a single gene. It follows from the "one gene-one enzyme" dictum that the primary defect should involve one enzyme. The broader statement of the concept "one gene-one polypeptide" suggests that more than one gene may direct the synthesis of one enzyme but leaves undisturbed the thesis that a genetic disease should cause one defective enzyme. Experience with an ever enlarging series of genetic diseases has supported the general applicability of the concept. There have been two noteworthy exceptions: maple syrup urine disease and orotic aciduria. The present study shows that familial hyperlysinemia is also an exception.

Familial hyperlysinemia was described in 1964. Elucidation of the enzyme defect followed a logical sequence. A severe reduction in the capacity to degrade lysine was demonstrated in two siblings after the administration of radioactive lysine $(26,27)$. Studies of skin fibroblasts grown in tissue culture identified the defective enzyme as lysine-ketoglutarate reductase (EC. 1.5.1.8) (6). This enzyme catalyzes the first step in the degradative pathway of lysine, the conversion of lysine to saccharopine (Fig. 1).

The recent death of an affected child in the original family has permitted an investigation of lysine metabolism in liver. The unexpected observation that more than one enzyme was defective led to further studies using skin fibroblasts of affected children. 